Kong. Res. J. 1(2): 68-71, 2014

Kongunadu Arts and Science College, Coimbatore

\title{
ETHNO-ECOLOGICAL STUDIES ON THE MEDICINAL PLANTS OF WESTERN GHATS REGION WITH SPECIAL REFERENCE TO VALPARAI TRIBES
}

\author{
Nithya Jeniffer, $P_{.}{ }^{1 *}$ and Manish Kumar ${ }^{2}$, and K. Logan Kumar ${ }^{1}$ \\ ${ }^{1}$ PG and Research Department of Zoology, Kongunadu Arts and Science College, Coimbatore- 641029. \\ ${ }^{2}$ Environmental Impact Assessment Division Sálim Ali Centre for Ornithology and \\ Natural History (SACON), Anaikatti (PO), Coimbatore - 641108 \\ *E-mail: jenii@rediffmail.com
}

\begin{abstract}
Traditional knowledge on plant has a long-standing history in many indigenous communities, and continues to provide useful tools for treating various diseases. Tribal communities living in biodiversity rich areas possess a wealth of knowledge on the utilization and conservation of food and medicinal plants. They are well versed in the usage of plant for treating various diseases. The present study carryout by survey method aimed to identifying the plants used for the general health of the tribal communities such as Kadar, Muthuvar and Malai Malasars of Western Ghats region. Ethno medicinal information was gathered through questionnaire from the majority of tribal people of Valparai hills Coimbatore, Tamil Nadu. All the traditional and other knowledge related to the collection and consumption of the medicinal plants, their environment on which communities depends was documented. The present study observed that, the tribal peoples from valparai having knowledge of 29 species on the traditional medicine. These tribes are one of the major conservators of environments. Their traditional knowledge can be utilized for the breeding technology of variety of threatened species and develop for the biodiversity conservation as well as for pharmacological research in various dimensions.
\end{abstract}

Keywords: Valparai tribes, Traditional knowledge, Ecological studies, Medicinal plants.

\section{INTRODUCTION}

India is proud to be rich in biodiversity possess about $8 \%$ of the estimated biodiversity of the world with around 12600 species. It is one of the 12 mega biodiversity centers with 2 hot spots of biodiversity in the Western Ghats and North-eastern region. It's also rich in ethnic diversity, there are about 67.37 million tribal people belonging to 537 tribal groups living in different geographical locations with various subsistence patterns (Amuthavalluvan 2011, Shanmugam et al., 2012).These tribal groups living in diversity rich areas possess a wealth of knowledge and skills on the utilization and conservation of food and medicinal plants. Ethnobotany is the scientific study of the relationships that exists between people and plants. Since the beginning of civilization, people have used plants as medicine. The World Health Organization (WHO, 2005) has estimated that $80 \%$ of the populations of developing countries still rely on traditional medicines, mostly plant drugs, for their primary health care needs. Demand for medicinal plant is increasing in both developing and developed countries due to growing needs of natural products being non-toxic and consider of no sideeffects, apart from availability at affordable prices. The medicinal plant sector has traditionally occupied a pivotal position in the socio cultural, spiritual and medicinal areas of rural and tribal families. It is estimated that tribal people of Tamil Nadu occupy $1.05 \%$ of the total state population and $0.77 \%$ of the total tribal population of the country. Ministry of Tribal affairs has released a list of tribal communities in India for each state and Tamil Nadu contains 36 types of tribal communities and they are distributed in different districts in the forests and adjoining areas.

The practices of traditional medicine are based on hundreds of years of belief and observations, which predate the development and spread of modern medicine (Aburjai et al., 2007). In developing countries, there is an increasing attempt to incorporate traditional medicines, especially herbal preparations in the local health care systems and a modernize preparations in the local health care systems and a modernized people are increasingly turning to herbal medicine (Njoroge and Wondimu et al., 2007). In India, medicinal plants are widely used by all sections of the population with an estimated 7500 species of plants used by several ethnic communities and it is known that India has the second largest tribal population in the world after Africa (Kala 2005). With enormously diversified ethnic groups and rich biological resources, India represents one of the great emporia of ethnobotanical wealth. Even today, tribal communities in India still collect and preserve locally available wild and cultivated plant species and 
practice herbal medicine to treat a variety of diseases and disorders (Mahishi et al.,2005).

\section{2 .MATERIALS AND METHODS}

\subsection{Study area}

The Western Ghats are globally recognized for their biological diversity and extend along the west coast of India from the River Tapti in the north almost to the southern tip of the peninsula. Toward its southern ranges lie the Anamalai hills ('elephant hills' in Tamil), an important conservation area in the southern Western Ghats. The present study was carried out in Indira Gandhi Wildlife Sanctuary (earlier known as the Anamalai Wildlife Sanctuary, $987 \mathrm{~km}^{2}, 10^{\circ} 12^{\prime} \mathrm{N}$ to $10^{\circ} 35^{\prime} \mathrm{N}$ and $76^{\circ} 49^{\prime} \mathrm{E}$ to $77^{\circ}$ $24^{\prime}$ E) particularly Valparai plateau fringed largely by tea estates. The altitude within the sanctuary ranges from $220 \mathrm{~m}$ in the foothills along the northern fringes to $2,513 \mathrm{~m}$ in the Grass Hills at the southern portion of the reserve. (Chandi, 2008). These hill ranges have been home to indigenous communities of different ethnic origin such as the Kadar, Muthuvar and Malai Malasars. The study was conducted in three types of tribal communities to ascertain the detailed information on the traditional healing potential of tribes inhabit the forest areas in Valparai , Coimbatore district of Tamil Nadu, South India.

\subsection{Methods}

The Ethnobotanical data were collected from December 2012 to November 2013 according to the methodology suggested by Jain, 2001. The ethnomedicinal data (local name, mode of preparation, medicinal uses) were collected through questionnaire, interviews and discussions among the tribal practitioners in their local language. Our questionnaire allowed descriptive responses on the plant prescribed, such as part of the plant used, medicinal uses, detailed information about mode of preparation (i.e., decoction, paste, powder and juice), and form of usage either fresh or dried and mixtures of other plants used as ingredients. They were selected based on their knowledge of medicinal plants either for self-medication or for treating others.

The species mentioned by the informants were taxonomically identified.

\section{RESULTS AND DISCUSSION}

The result shows that the tribal communities of Valparai especially Kadar, Muthuvar and Malai Malasars possess a very good knowledge of medicinal plants available in the forest area. The study includes information on 29 plant species belonging to 18 families (Table 1). They are used to treat liver and stomach diseases, snake bite, piles, skin diseases, hair problems, appetizer, antiseptic, gonorrhea, urinary infections, fever, cough, wound healing, anti diabetic etc. Many species of the family Amaranthaceae, Moraceae, Solanacea, Tiliacea are frequently used.

Valparai tribal practitioners use specific plant parts and specific dosages for the treatment of ailments. The plant products are consumed raw or in the form of a decoction, as infusion for oral treatment and as burnt product, ointments or raw paste when applied externally. The parts of the plants mostly used for medicinal purposes are leaves, root, stem, fruits, and the whole plant, barks (root and stem) and flowers (including the flowering heads). (Fig 2\& 3). The most common forms of preparing the medicines from the plants are fresh juice, powder, paste, and decoction. Internal uses invariably predominate over external uses. Juice (almost mixed with water and goat's or cow's milk) and paste are the main methods of preparation, either for oral or for external administration. For topical use, the most important methods used are direct application of the paste or ointment (with oil). Among the different plant parts used by the tribal communities of Valparai, leaves constituted the major portion of the medicine. These indigenous methods of treatment based on medicinal plants are still an important part of their life.

All ethno medicinal plants documented in the presence study have continuously been used and also revealed that some of them are less known and some of them supplements the available earlier data. Based on their experience and common sense, the Valparai tribal communities (Kadar, Muthuvar and Malai Malasars) have the capability to search for number of uses of plants at the same time they have also the talent to exploit the plants of even a new area where they have settled. The study indicated that, the study area was rich in medicinal plants and provides evidence that medicinal plants continue to play an important role in the healthcare system of this tribal community. Therefore it is an urgent need for the scientific awareness about the importance of biodiversity and medicinal plants for the sustainable utilization of natural resources.

\section{REFFERENCE}

Aburjai, T., M. Hudaib, R. Tayyem M. Yousef and M, Qishawi, (2007). Ethnopharmacological survey of medicinal herbs in Jordan, theAjloun Heights region. J Ethnopharmacol 110: 294-304 
Amuthavalluvan, V. (2011). Ethno medicinal practices and traditional healing system of Kattunayakan in Tamilnadu: An anthropological study. Int . Mult Res 1(7): 47-51

Chandi, M., (2008). Tribes of the Anamalais: livelihood and resource-use patterns of communities in the rainforests of the Indira Gandhi Wildlife Sanctuary and Valparai plateau. NCF Technical Report No. 16, Nature Conservation Foundation, Mysore.

Jain, SK. (2001). Ethnobotany in Modern India. Phytomorphology Golden Jubilee Issue: Trends in Plant Sciences 39-54.

Kala, C .P. (2005). Current status of medicinal plants used by traditional vaidyas in Uttaranchal State of India. Ethnobot. Res. Appl. 3: 267-27

Mahishi, P., B.H. Srinivasa and M.B. Shivanna, (2005) Medicinal plant wealth of local communities in some villages in Shimoga District of Karnataka, India. J Ethnopharmacol; 98: 307-312.

Njoroge, G.N. and R.W. Bussmann, (2007) Ethno therapeautic management of skin diseases among the Kikuyus of Central Kenya. J Ethnopharmacol. 111: 303-307

Shanmugam, S., K. Rajendran and K. Suresh, (2012). Traditional uses of medicinal plants among the rural people in Sivagangai district of Tamil Nadu, Southern India. Asian Pac J Trop Biomed 5: 429-S434

Wondimu,T., Z. Asfaw and E. Kelbessa, (2007) Ethnobotanical study of medicinal plants around 'Dheeraa' town, Arsi Zone, Ethiopia. J Ethnopharmacol 112: 152-161

World Health Organization. (2005). WHO Traditional Medical Strategy, Geneva.

Table 1: Medicinal plants and their product consumed by Tribal peoples of Valparai-Western Ghats

\begin{tabular}{|c|c|c|c|c|c|}
\hline S.No. & Binominal/Common name & Family & Habit & $\begin{array}{l}\text { Part (s) } \\
\text { used }\end{array}$ & Diseases \\
\hline 1 & $\begin{array}{l}\text { Alternanthera sessilis } \\
\text { DC/Ponnakanni }\end{array}$ & Amaranthaceae & Herb & Seed & $\begin{array}{l}\text { As Contraceptive, } \\
\text { Hair tonic \& }\end{array}$ \\
\hline 2 & Achuranthus asnera I /Navurivi & & & & Leucoderma \\
\hline 3 & $\begin{array}{l}\text { Achyranthus aspera L./Nayurivi } \\
\text { Amaranhus spinosus/Mullukerai }\end{array}$ & Amaranthaceae & Herb & Leaves & $\begin{array}{l}\text { Wound healing, Dog } \\
\text { bites. }\end{array}$ \\
\hline & $\begin{array}{l}\text { rhavia diffusa } \\
\text { L./Mukkarattai }\end{array}$ & Amaranthaceae & Herb & leaves & $\begin{array}{l}\text { Reduses urination in } \\
\text { urinary duct }\end{array}$ \\
\hline & ngium salvifolium & Nyctaginaceae & Herb & Leaves & Diuretic \\
\hline & Wang./Azhinzal & Alangiaceae & Shrub & Stem Bark, & Stomach Problems, \\
\hline 6 & $\begin{array}{l}\text { Cissus quadrangularis } \\
\text { L./Pirandai }\end{array}$ & Vitaceae & Climber & $\begin{array}{l}\text { Stem \& } \\
\text { Leaves }\end{array}$ & $\begin{array}{l}\text { Bone- -breakage, } \\
\text { appetizer. }\end{array}$ \\
\hline $\begin{array}{l}7 \\
8\end{array}$ & $\begin{array}{l}\text { Ficus bengalensis L./Aal } \\
\text { Lantana indica Roxb./ }\end{array}$ & $\begin{array}{l}\text { Moraceae } \\
\text { Verbenaceae }\end{array}$ & $\begin{array}{l}\text { Tree } \\
\text { Shrub }\end{array}$ & $\begin{array}{l}\text { Stem Bark, } \\
\text { Leaves }\end{array}$ & $\begin{array}{l}\text { Wound healing. } \\
\text { Anti Inflammatory, }\end{array}$ \\
\hline 9 & $\begin{array}{l}\text { Unnichedi } \\
\text { Syzygium sp/ Naval }\end{array}$ & Mrytaceae & Tree & Bark Seeds & $\begin{array}{l}\text { Antiseptic } \\
\text { Anti Diabetic }\end{array}$ \\
\hline 10 & Artocarpus sp./Cheeni pala & Moraceae & Tree & $\begin{array}{l}\text { Bark and } \\
\text { seed }\end{array}$ & $\begin{array}{l}\text { Liver and stomach } \\
\text { diseases }\end{array}$ \\
\hline 11 & Cassia tora /Thakara & Caesalpiniaceae & Herb & $\begin{array}{l}\text { Leaves } \\
\text { roots \& } \\
\text { seeds }\end{array}$ & Gonorrhea \\
\hline 12 & $\begin{array}{l}\text { Cymbopogon citratus } \\
\text { Stapf./lemon grass }\end{array}$ & Poaceae & Herb & leaves & Body pain \\
\hline 13 & $\begin{array}{l}\text { Coccinia grandis (L)Voigt./kovai } \\
\text { kai }\end{array}$ & Cucurbitaceae & Climber & leaves & $\begin{array}{l}\text { Piles and Skin } \\
\text { diseases }\end{array}$ \\
\hline 14 & Centella asiatica Urb/Vallarai & Apiaceae & Herb & leaves & Memory power \\
\hline 15 & $\begin{array}{l}\text { Solanum surattense } \\
\text { burm.f./Kantankathari }\end{array}$ & Solanaceae & Herb & leaves & $\begin{array}{l}\text { Cough and asthma } \\
\text { and fever }\end{array}$ \\
\hline 16 & S. torvum Sw./Sundai & Solanaceae & Herb & leaves & Skin diseases \\
\hline 17 & Carisa spinarum L./kalakai & Apocynaceae & Shrub & fruit & Wound healing \\
\hline
\end{tabular}




\begin{tabular}{|c|c|c|c|c|c|}
\hline 8 & F.glomerata Roxb./Athi & Moraceae & Tree & $\begin{array}{l}\text { Bark and } \\
\text { fruit }\end{array}$ & $\begin{array}{l}\text { Insect bite and skin } \\
\text { diseases }\end{array}$ \\
\hline 19 & $\begin{array}{l}\text { Grewia hirsuta } \\
\text { Vahl./Sirukadalai }\end{array}$ & Tiliacea & Shrub & roots & $\begin{array}{l}\text { Treatment for } \\
\text { swellings }\end{array}$ \\
\hline 20 & G. tiliaefolia vahl/Sadachi & Tiliacea & Tree & fruit & Stomach problem \\
\hline 21 & G. villosa Wild/Perukadalai & Tiliacea & Shrub & fruit & $\begin{array}{l}\text { skin diseases and } \\
\text { intestinal problem, } \\
\text { antibiotic }\end{array}$ \\
\hline 22 & S. gardneri thw./Neer naval & Mrytaceae & Tree & Bark Seeds & Anti Diabetic \\
\hline 23 & $\begin{array}{l}\text { Ziziiphus mauritiana } \\
\text { Lam/Elanthai }\end{array}$ & Rhamnaceae & Tree & leaves & $\begin{array}{l}\text { Skin diseases and } \\
\text { hair treatment }\end{array}$ \\
\hline 24 & Terminalia bellirica Roxb. & Combretaceae & Tree & frui & Stomach problem \\
\hline 25 & Ficus religiosa/athi & Moraceae & Tree & $\begin{array}{l}\text { Bark and } \\
\text { fruit }\end{array}$ & $\begin{array}{l}\text { Decoction - } \\
\text { Gonorrhea }\end{array}$ \\
\hline 26 & $\begin{array}{l}\text { Barleria prionitis/ } \\
\text { kattukanagambaram }\end{array}$ & Acanthaceae & Shrub & leaves & Headache \\
\hline 27 & Solanum nigrun L/sukutti keerai & Solanacea & Herb & leaves & Stomach problem \\
\hline 28 & $\begin{array}{l}\text { Hibiscus rosasinesis } \\
\text { /Semparuthi }\end{array}$ & Malvaceae & Shrub & $\begin{array}{l}\text { Leaves and } \\
\text { flowers }\end{array}$ & Hair tonic \\
\hline 29 & $\begin{array}{l}\text { Curcuma aromatica/Kasturi } \\
\text { manjal }\end{array}$ & Zingiberaceae & Shrub & Rhizome & Pimple \\
\hline
\end{tabular}

Figure 1: Percentage of plant parts used for the preparation in Different Category

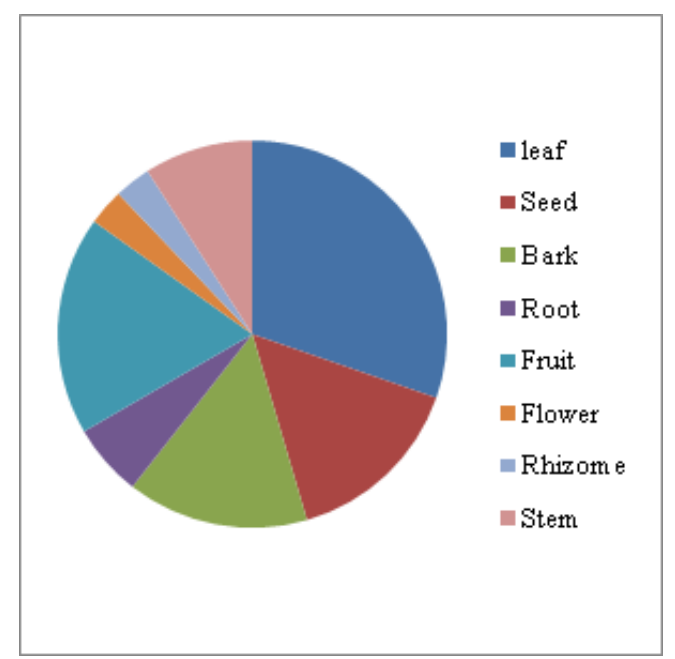

Figure 2: Medicinal plants of medicine by tribal people, Valparai region.

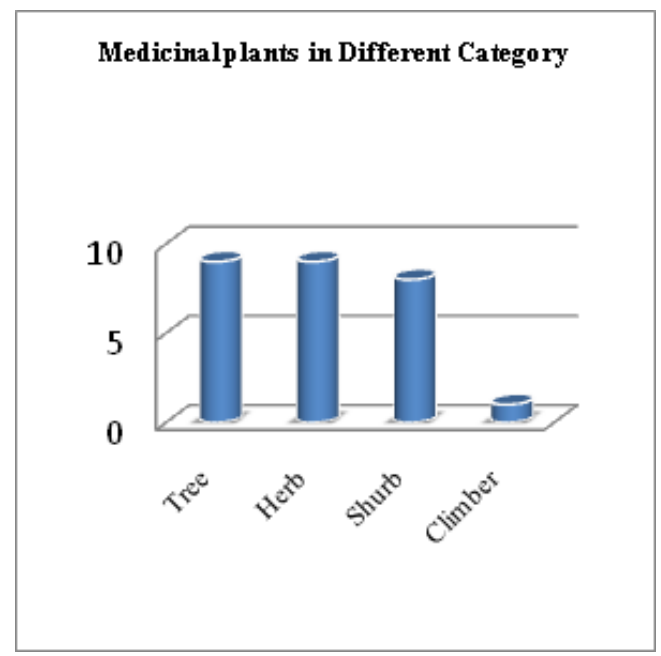

